\title{
PENGOLAHAN AIR GAMBUT DENGAN KOMBINASI PROSES FLOKULASI DAN MIKROFILTRASI
}

\author{
N. Aryanti dan H. Susanto ${ }^{*}$
}

\begin{abstract}
Abstrak
Makalah ini membahas gabungan proses flokulasi dan membran mikrofiltrasi untuk pengolahan air gambut. Penelitian dilakukan dengan menggunakan air gambut sintetis yang dibuat dari humic acid pada berbagai variasi konsentrasi. Validasi dilakukan dengan air gambut asli yang berasal dari daerah Riau dengan kadar organik $168,5 \mathrm{mg} \mathrm{L} \mathrm{KMnO}_{4}$. Sebagai flokulan digunakan $\mathrm{FeCl}_{3}$ dengan jenis membran hollow fiber polisulfon. Respon yang diamati adalah fluk dan rejeksi kadar organik. Percobaan dilakukan dengan variasi tekanan 0,4-1,6 bar dan konsentrasi flokulan $0-40 \mathrm{mg} \mathrm{L}$. Hasil penelitian memumjukkan bahwa pengaruh tekanan operasi akan meningkatkan fluk. Kenaikan konsentrasi flokulan dari 0 - $40 \mathrm{mg} L$ menyehabkan fluk yang didapatkan semakin turun dengan rejeksi kadar organik naik. Kondisi operasi terbaik yang didapatkan yaitu pada tekanan 1,2 bar dan konsentrasi flokulan $40 \mathrm{mg} L$ untuk air gambut sintetis sedangkan untuk air gambut asli pada tekanan I bar dan konsentrasi flokulan $30 \mathrm{mg} L$.
\end{abstract}

Kata kunci : flokulan; membran mikrofiltrasi; fluk; rejeks

\section{Pendahuluan}

Pertambahan jumlah penduduk dan perkembangan teknologi membawa konsekuensi logis peningkatan kebutuhan air yang mengakibatkan terjadinya ketidakseimbangan antara sumber air yang tersedia dengan kebutuhan air. Salah satu sumber daya air yang banyak terdapat di Indonesia adalah air gambut. Menurut tim Pusat Penelitian Tanah dan Agroklimat Departemen Pertanian (Widjaja-Adhi, 2000), lahan gambut ini berada dalam lahan rawa Indonesia yang luasnya sekitar 33 juta hektar, tersebar di Sumatera (41,4 persen), Kalimantan (22,8 persen), Papua (23 persen), Sulawesi (1,6 persen), dan Halmahera-Seram $(0,5$ persen).

Kendala utama yang didapati di daerah ini adalah langkanya ketersediaan air bersih, karena sumber baku pada lahan tersebut mempunyai tingkat keasaman yang tinggi, keruh dan berwarna merah kecoklatan. Karakteristik air gambut secara kuantitatif yaitu : kadar alkalinitas rendah, air keruh dan berwarna merah kecoklatan, kandungan garam mineral relatif tinggi, tingkat keasaman tinggi, dan konsentrasi total karbon organik (TOC) tinggi akibat pelapukan bahan organik yaitu asam humic dan fulfik. Warna coklat air gambut berasal dari zat-zat humus yang terdapat pada tanah dan gambut, merupakan zat polimer yang mengandung persenyawaan asam karboksil dan gugusan fenol. Humus dibagi menjadi 3 bagian yaitu: humic acid, humin dan fulvic acid. Fulvic acid larut pada semua $\mathrm{pH}$, humic acid larut pada $\mathrm{pH}>2$ dan humin tidak larut. Sifat asam air gambut disebabkan oleh adanya tanah lempung mengandung sulfida, yang kemudian teroksidasi menjadi asam sulfat.
Metode konvensional (koagulasi, sedimentasi, dan filtrasi) yang digunakan selama ini telah mampu mengolah air gambut, namun kadar zat organik air hasil olahannya masih diatas standar baku mutu yang ditetapkan oleh Departeman Kesehatan. Kendala lain dengan penggunaan proses konvensional tersebut adalah jumlah koagulan yang sangat banyak, yang pada akhirnya akan memerlukan biaya besar dan berdampak negatif pada lingkungan (Schafer, 2000).

Teknologi membran merupakan teknologi yang relatif baru dalam pengolahan air. Teknologi ini dapat mengatasi kelemahan-kelemahan yang terdapat dalam proses pengolahan air gambut secara konvensional karena membran merupakan teknologi yang sangat handal dalam pengolahan air. Secara umum penggunaan teknologi membran mempunyai kelebihankelebihan antara lain: konsumsi energi rendah, dapat digabung dengan proses pemisahan yang lain, modular, membran mempunyai jenis yang sangat banyak baik material, bentuk maupun ukurannya dan pada umumnya proses menggunakan membran tidak memerlukan bahan kimia tambahan (Wenten, 2002).

Masalah-masalah yang ditimbulkan pada proses konvensional dapat diatasi dengan integrasi proses flokulasi dan membran mikrofiltrasi. Kombinasi flokulasi dan penggunaan membran mikrofiltrasi sangat berperan dalam menurunkan kadar organik dan penghilangan partikel mikro dan makro yang harus dihindari keberadaannya dalam air bersih. Pada umumnya mikrofiltrasi memisahkan partikel tersuspensi baik makro maupun mikro. Air gambut banyak mengandung zat-zat organik yang mungkin masih dapat melewati membran mikrofiltrasi. Oleh karena itu pada tahap awal perlu dilakukan perlakuan awal menggunakan flokulan yang bertujuan untuk

\footnotetext{
$\left.{ }^{*}\right)$ Jurusan Teknik Kimia Fakultas Teknik UNDIP 
menghilangkan zat-zat organik dan membentuk flokflok. Selanjutnya dengan membran mikrofiltrasi, air gambut olahan akan dipisahkan dari partikel makro dan partikel mikro yang keberadaanya dalam air minum tidak dibolehkan serta sebagian zat-zat yang tidak dapat membentuk flok (Schafer, 1998).

Permasalahan yang timbul adalah minimnya penelitian-penelitian yang telah dilakukan sehingga menyebabkan tidak mungkinnya implementasi teknologi ini. Penelitian ini diharapkan dapat memberikan sumbangan pengetahuan bagi implementasi proses flokulasi dan mikrofiltrasi untuk pengolahan air dengan kandungan senyawa organik alam.

\section{Metodologi Penelitian}

Penelitian dilakukan dengan menggunakan air gambut sintetik yang terbuat dari laruatan humic acid pada berbagai konsentrasi yaitu $40-280 \mathrm{mg} / \mathrm{L}$ dan air gambut dari Riau. Sebagai flokulan digunakan $\mathrm{FeCl}_{3}$. Pada tahap awal dilakukan analisis air gambut yang meliputi analisis kadar organik. Perlakuan awal yang dilakukan adalah flokulasi dengan variasi konsentrasi $\mathrm{FeCl}_{3}$ untuk menghilangkan zat-zat organik, kemudian dilewatkan melalui modul membran mikrofiltrasi dengan variasi tekanan operasi. Membran yang digunakan adalah hollow fiber polisulfon dengan luas permukaan membran $4,48 \times 10^{-3} \mathrm{~m}^{2}$. Konsentrasi flokulan divariasikan dari $0-40 \mathrm{ppm}$ dan tekanan operasi dari $0,4-1,6$ bar. Respon yang diamati adalah fluk permeat dan rejeksi organik yang dianalisis dengan metode permanganometri. Rangkaian alat percobaan disajikan pada Gambar 1.

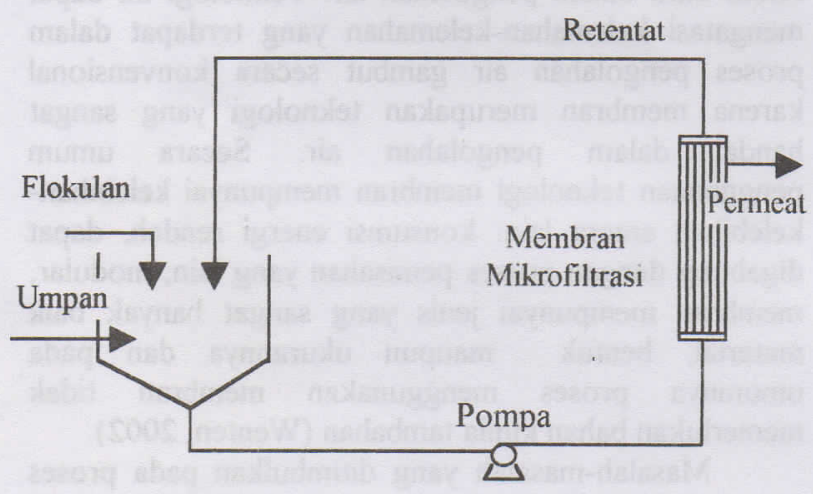

Gambar 1. Rangkaian Alat Percobaan

\section{Hasil dan Pembahasan \\ Karakterisasi membran}

Tujuan karakterisasi membran adalah untuk mengetahui kinerja awal dari membran. Percobaan dilakukan dengan cara mengalirkan aquadest ke dalam modul membran pada tekanan $0,4-1,6$ bar. Hasil percobaan disajikan pada Gambar 2

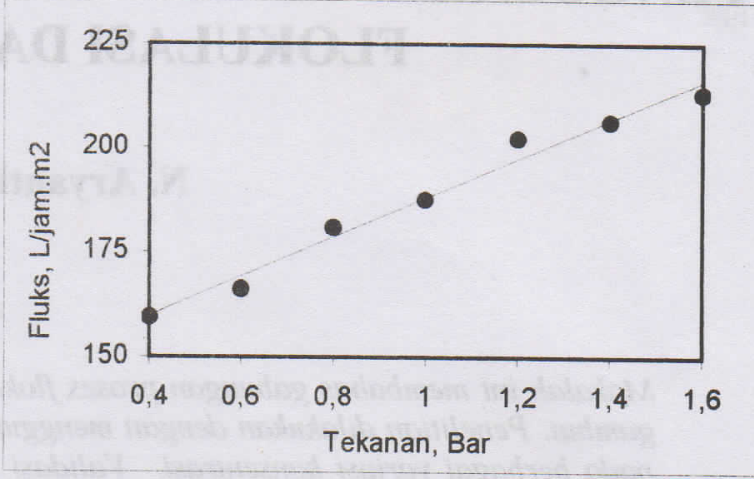

Gambar 2. Hubungan Tekanan dengan Fluk pada Aquadest

Gambar 2 menunjukkan bahwa kenaikan tekanan akan meningkatkan harga fluk aquadest, hal ini disebabkan karena driving force proses mikrofiltrasi adalah perbedaan tekanan. Jika perbedaan tekanan meningkat maka fluk aquadest yang melewati membran akan meningkat. Hasil yang diperoleh sesuai dengan teori bahwa hubungan antara $\Delta \mathrm{P}$ dan fluk linier sehingga peningkatan $\Delta \mathrm{P}$ akan meningkatkan fluk secara linier. Selain itu dari gambar tersebut dapat diketahui permeabilitas awal membran (gradien grafik) sebesar $46,88 \mathrm{~L} / \mathrm{m}^{2}$ jam bar

\section{Studi pengaruh konsentrasi flokulan terhadap fluk dan rejeksi}

Untuk mengetahui pengaruh konsentrasi flokulan terhadap fluk dan rejeksi dilakukan percobaan menggunakan air gambut asli dan air gambut sintetis dengan konsentrasi humic acid $100 \mathrm{mg} / \mathrm{L}$ pada tekanan 1 bar dan variasi konsentrasi flokulan $0-40 \mathrm{mg} / \mathrm{L}$. Hasil percobaan disajikan pada Gambar 3 dan 4.

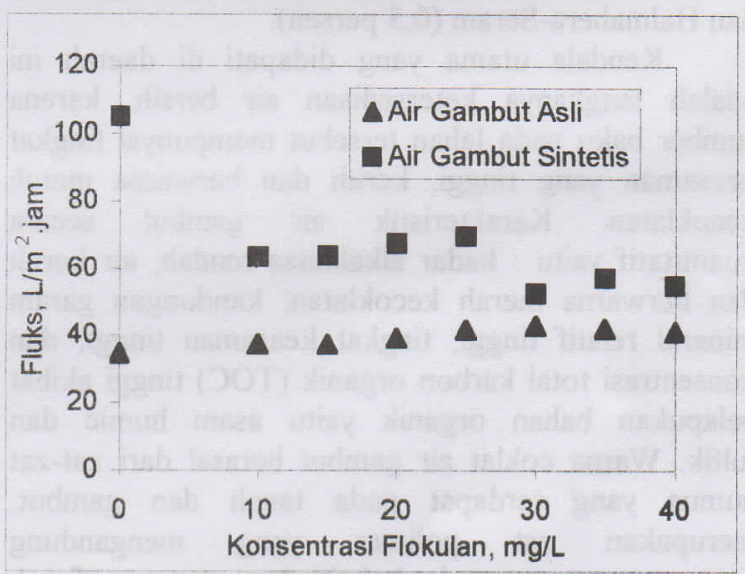

Gambar 3 Pengaruh Konsentrasi Flokulan Terhadap Fluk

Air gambut terdiri dari padatan terlarut dan padatan tersuspensi. Dengan penambahan flokulan maka beberapa padatan terlarut akan membentuk flokflok yang memiliki ukuran partikel besar. Gambar 3 menunjukkan bahwa secara umum kenaikan 
konsentrasi flokulan akan menurunkan fluk permeat, hal ini terjadi karena penambahan flokulan mengakibatkan flok-flok yang terbentuk semakin banyak, sehingga fouling yang terjadi semakin tebal dan menyebabkan tertutupnya pori-pori membran sehingga fluk akan turun (Shafer, 1998). Fenomena yang terjadi pada air gambut asli memiliki karakteristik yang sama dengan air gambut sintetis. Pada air gambut asli fluk yang diperoleh lebih kecil dibandingkan dengan air gambut sintetis karena air gambut asli mempunyai kandungan organik yang jauh lebih besar sehingga flok-flok yang terbentuk lebih banyak. Flok tersebut akan membentuk foulant yang menyebabkan penurunan fluk permeat.

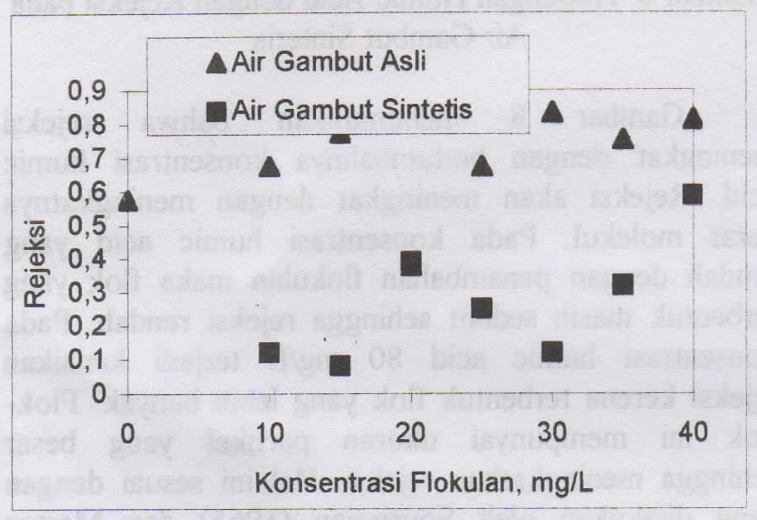

Gambar 4. Pengaruh Konsentrasi Flukulan Terhadap Rejeksi

Gambar 4 memperlihatkan bahwa secara umum dengan penambahan konsentrasi flokulan maka rejeksi yang diperoleh semakin tinggi. Hal ini dipengaruhi oleh humic acid yang membentuk flokflok semakin banyak, sehingga akan meningkatkan kualitas permeat (Aoustin dkk 1999).

Dari Gambar 3 dan 4 dapat diketahui kondisi terbaik operasi mikrofiltrasi pada air gambut sintetis yaitu pada penambahan flokulan dengan konsentrasi $40 \mathrm{mg} / \mathrm{L}$. Penambahan konsentrasi flokulan akan meningkatkan rejeksi dan rejeksi tertinggi diperoleh pada konsentrasi flokulan $30 \mathrm{mg} / \mathrm{L}$. Kondisi operasi terbaik diperoleh pada penambahan flokulan 30 $\mathrm{mg} / \mathrm{L}$.

\section{Studi pengaruh tekanan terhadap fluk dan rejeksi}

Secara teoritik kinerja proses sangat dipengaruhi oleh tekanan. Penelitian untuk mengetahui pengaruh tekanan terhadap kinerja proses dilakukan pada konsentrasi humic acid $100 \mathrm{mg} / \mathrm{L}$ dan konsentrasi flokulan $40 \mathrm{mg} / \mathrm{L}$ dengan variasi tekanan $0,4-1,6$ bar. Hasil percobaan disajikan pada Gambar 5 dan 6 .

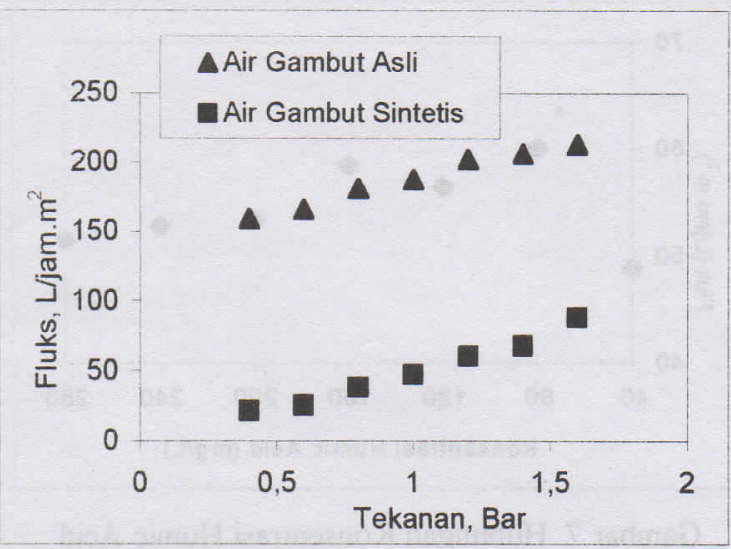

Gambar 5 Hubungan Tekanan dengan Fluks pada Air Gambut Sintetis

Gambar 5 menunjukkan bahwa kenaikan tekanan menyebabkan kenaikan fluk. Hal ini dapat dijelaskan dengan hukum Darcy yang menyatakan fluk berbanding lurus dengan tekanan. Kenaikan tekanan akan meningkatkan penetrasi umpan ke dalam membran sehingga fluk akan naik.

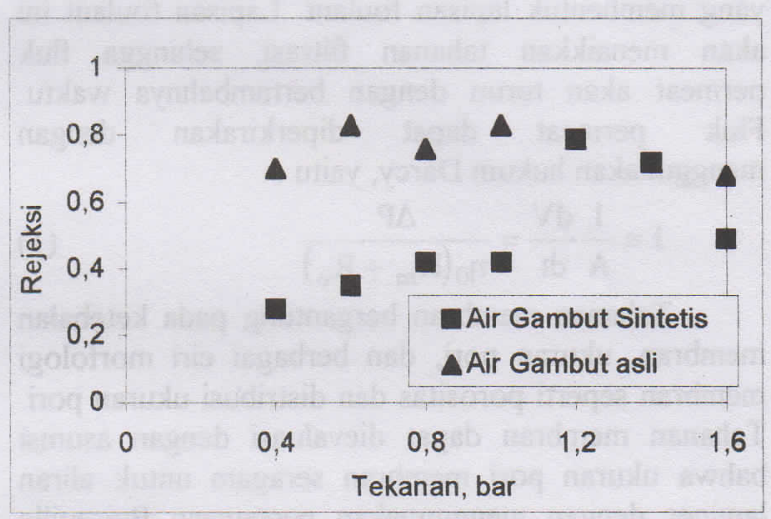

Gambar 6. Pengaruh Tekanan Terhadap Rejeksi

Gambar 6 menunjukkan dengar kenaikan tekanan sampai batas tertentu ( 1.2 bar) terjadi kenaikan rejeksi yang disebabkan foulant yang menumpuk semakin bertambah. Penumpukan foulant ini akan berfungsi sebagai membran kedua dimana air gambut harus melewatinya sehingga rejeksi akan naik. Pada kenaikan tekanan diatas 1.2 bar terjadi penurunan rejeksi, hal ini terjadi karena foulant yang terjadi pada permukaan membran dapat lolos melewati pori-pori membran (Mallevialle dkk, 1996).

\section{Studi pengaruh konsentrasi humic acid terhadap fluk dan rejeksi}

Untuk mengetahui pengaruh konsentrasi humic acid terhadap fluk dan rejeksi dilakukan percobaan dengan memvariasikan konsentrasi humic acid dari 40 $-280 \mathrm{mg} / \mathrm{L}$ dan dilakukan pada tekanan 1.2 bar dengan konsentrasi flokulan $40 \mathrm{mg} / \mathrm{L}$. Hasil percobaan dapat dilihat pada Gambar 7 dan 8 . 


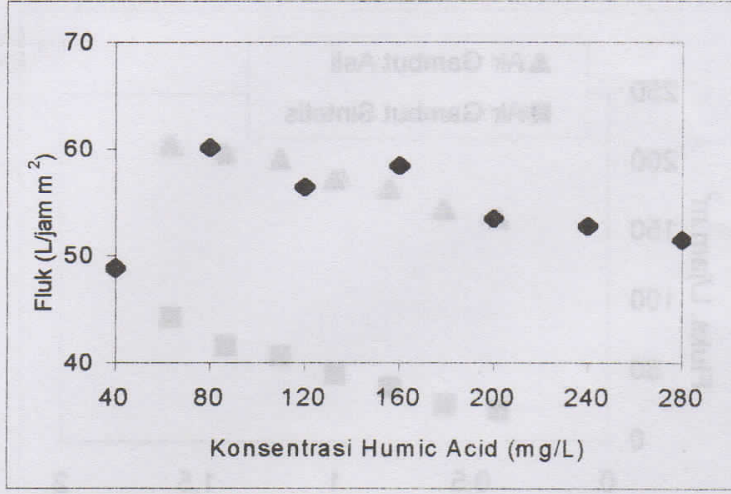

Gambar 7. Hubungan Konsentrasi Humic Acid dengan Fluk pada Air Gambut Sintetis

Gambar 7 menunjukkan bahwa kenaikan konsentrasi humic acid pengaruhnya tidak signifikan terhadap fluk permeat. Hal ini dapat dijelaskan dengan hukum Darcy yang menyatakan fluk berbanding terbalik dengan tahanan membran dan tahanan foulant. Pada proses mikrofiltrasi akan terjadi akumulasi partikel pada permukaan membran yang membentuk lapisan foulant. Lapisan foulant ini akan menaikkan tahanan filtrasi, sehingga fluk permeat akan turun dengan bertambahnya waktu. Fluk permeat dapat diperkirakan dengan menggunakan hukum Darcy, yaitu

$$
\mathrm{J} \equiv \frac{1}{\mathrm{~A}} \frac{\mathrm{dV}}{\mathrm{dt}}=\frac{\Delta \mathrm{P}}{\eta_{0}\left(\mathrm{R}_{\mathrm{m}}+\mathrm{R}_{\mathrm{c}}\right)}
$$

Tahanan membran bergantung pada ketebalan membran, ukuran pori, dan berbagai ciri morfologi membran seperti porositas dan distribusi ukuran pori. Tahanan membran dapat dievaluasi dengan asumsi bahwa ukuran pori membran seragam untuk aliran laminer dengan menggunakan persamaan Poiseuille yaitu

$$
\mathrm{Rm}=\frac{8 \delta \mathrm{m}}{\mathrm{N} \pi \mathrm{r}_{\mathrm{p}}{ }^{4}}
$$

Bila diasumsikan ukuran pori membran seragam maka tahanan membran berbanding terbalik dengan jumlah pori membran. Peningkatan konsentrasi akan meningkatkan pembentukan lapisan foulant, sehingga menurunkan jumlah pori membran dan radius pori efektif tetapi meningkatkan tahanan partikel foulant. Penurunan jumlah pori dan radius pori akan meningkatkan tahanan membran sehingga fluk akan mengalami penurunan (Zeman dan Zydney, 1996).

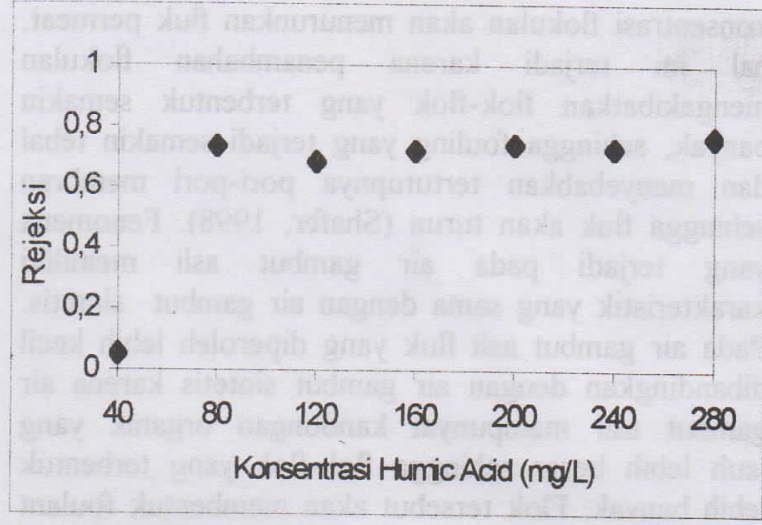

Gambar 8. Hubungan Humic Acid dengan Rejeksi pada Air Gambut Sintetis

Gambar 8 menunjukkan bahwa rejeksi meningkat dengan bertambahnya konsentrasi humic acid. Rejeksi akan meningkat dengan meningkatnya berat molekul. Pada konsentrasi humic acid yang rendah dengan penambahan flokulan maka flok yang terbentuk masih sedikit sehingga rejeksi rendah. Pada konsentrasi humic acid $80 \mathrm{mg} / \mathrm{L}$ terjadi kenaikan rejeksi kerena terbentuk flok yang lebih banyak. Flokflok ini mempunyai ukuran partikel yang besar sehingga meningkatkan rejeksi. Hal ini sesuai dengan yang dilakukan oleh Sourirajan (1965) dan Merten (1968) yang menyatakan bahwa rejeksi komponen organik meningkat dengan meningkatnya berat molekul. Pada penambahan konsentrasi humic acid hasil rejeksi yang didapatkan cenderung konstan karena fungsi flokulan mengikat zat-zat organik sudah maksimum (Mallevialle dkk, 1996).

\section{Studi dinamika fluk terhadap waktu operasi}

Studi dinamika fluk terhadap waktu operasi dilakukan dengan menggunakan air gambut asli dan air gambut sintetis $160 \mathrm{mg} / \mathrm{L}$ pada tekanan 1,2 bar dan konsentrasi flokulan $40 \mathrm{mg} / \mathrm{L}$ selama 6 jam. Pengukuran fluk dilakukan setiap 15 menit. Hasil percobaan disajikan pada Gambar 9.

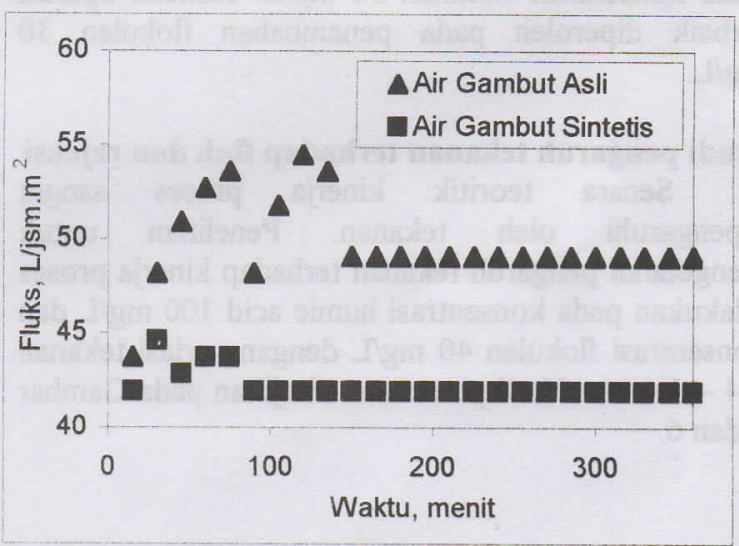

Gambar 9. Dinamika Fluk terhadap Waktu Operasi 
Penurunan fluk permeat akan terjadi dengan bertambahnya waktu operasi dan setelah dicapai keadaan tunak maka fluk akan konstan. Seperti terlihat pada Gambar 9 mula-mula fluk akan naik karena foulant yang terbentuk akan terbawa oleh aliran umpan sehingga foulant menipis kemudian akan terjadi penumpukan foulant lagi sehingga fluk cenderung turun dan akhirnya diperoleh fluk yang konstan pada menit ke-90. Ketika tahanan foulant relatif besar dibandingkan tahanan membran, penurunan fluk permeat dapat dikorelasikan dengan sejumlah endapan material pada permukaan membran. Dalam suatu periode waktu tertentu fluk permeat akan menurun sampai transport partikel ke endapan foulant pada membran seimbang dengan transport partikel dari foulant, dan fluk permeat mencapai nilai konstan (Belfort dkk, 1994).

Seperti terlihat pada Gambar 4, penurunan fluk permeat akan terjadi dengan bertambahnya waktu operasi dan setelah dicapai keadaan tunak maka fluk akan konstan. Harga fluks rata-rata untuk senyawa organik alam dan senyawa organik sintetis adalah $49,74 \mathrm{~L} / \mathrm{jam} \mathrm{m}^{2}$ dan $42,26 \mathrm{~L} / \mathrm{jam} \mathrm{m}^{2}$. Mula-mula fluks akan naik karena foulant yang terbentuk akan terbawa oleh aliran umpan sehingga foulant menipis kemudian akan terjadi penumpukan foulant lagi sehingga fluk cenderung turun dan akhirnya diperoleh fluk yang konstan (fluks kritik) pada menit ke-90 (untuk senyawa organik sintetis). Sedangkan untuk senyawa organik alam, fluks kritik dicapai pada menit ke-150.

\section{Kesimpulan}

Kenaikan fluk sangat signifikan dapat dicapai dengan meningkatkan tekanan operasi dari 0,4-1,6 bar. Selain itu kenaikan tekanan operasi akan meningkatkan rejeksi mencapai nilai maksimum. Kenaikan konsentrasi flokulan tidak signifikan mempengaruhi fluk tetapi menaikkan rejeksi zat organik. Fenomena yang terjadi pada air gambut asli memiliki karakteristik yang sama dengan air gambut sintetis. Kondisi operasi terbaik dalam pengolahan air gambut sintetis pada tekanan 1,2 bar dan konsentrasi flokulan $40 \mathrm{mg} / \mathrm{L}$ (fluk mencapai $46,72 \mathrm{~L} / \mathrm{jam}$ dan rejeksi $79 \%$ ). Pada air gambut asli hasil terbaik dicapai pada tekanan 1 bar dan konsentrasi flokulan $30 \mathrm{mg} / \mathrm{L}$ (fluk mencapai $47,5 \mathrm{~L} / \mathrm{jam} \mathrm{m}^{2}$ dan rejeksi $83,5 \%$ )

\section{Ucapan Terima Kasih}

Ucapan terima kasih kepada Direktorat

Pembinaan Penelitian dan Pengembangan Pemberdayaan Masyarakat, DIKTI yang telah membiayai penelitian ini melalui Program Kreatifitas Mahasiswa Penelitian.

\section{Daftar Notasi}

$$
\begin{array}{ll}
\mathrm{A} & =\text { luas permukaan membran }\left(\mathrm{m}^{2}\right) \\
\mathrm{J} & =\text { fluk permeat }\left(\mathrm{L} / \mathrm{jam} \mathrm{\textrm {m } ^ { 2 }}\right)
\end{array}
$$

$\mathrm{N} \quad=$ jumlah pori per luas membran

$\mathrm{R}_{\mathrm{c}} \quad=$ tahanan foulant

$\mathrm{R}_{\mathrm{m}} \quad=$ tahanan membran

$\mathrm{t} \quad=$ waktu (jam)

$\mathrm{V} \quad=$ volume permeat (Liter)

$\Delta \mathrm{P} \quad=$ tekanan (bar)

$\delta_{\mathrm{m}} \quad=$ tebal membran (meter)

$\eta_{0} \quad=$ viskositas permeat (centipoise)

\section{Daftar Pustaka}

Anonim, (2000), "Instalasi Pengolahan Air Gambut untuk Penyediaan Air Bersih", Pusat Penelitian dan Pengembangan Sumber Daya Air

Aoustin, E., Schafer, A.I., Fane, A.G. and Waite, TD, "Effect of Humic Substance and Colloid Interactions on Ultrafiltration Behaviour", Separation and Purufication Technology.

Belfort, G., Davis, R.H., and Zydney, A.L, (1994), "The Behavior of Suspensions and Macromolecular Solutions in Crossflow Microfiltration", Journal of Membrane Science, 96

Malleviale, J., Odendaal, P.E., and Wiesner, M.R., (1996), "Water Treatment Membrane Process", American Water Works Association Research Fondation, Lyonnaise des Eaux, Water Research Commision of South Africa.

Merten, (1968), "Water Treatment Membrane Process", American Water Works Association Research Fondation, Lyonnaise des Eaux, Water Research Commision of South Africa.

Mulder, M., (1996), “Basic Principles of membrane Technology", $2^{\text {nd }}$ edition, Kluwer Academic Publisher, Dordrecht.

Schafer, A.I., Fane, A.G., and Waite, T.D., (1998), "Chemical Addition Prior to Membrane Processes for Natural Organic Matter (NOM) Removal", Proceedings $8^{\text {th }}$ Gothenburg Symposium, Prague.

Schafer, A.I., Fane, A.G., and Waite, T.D., (2000), "Membrane Processes for Natural Organic Matter (NOM) Removal in Water Treatment", IWA Water, Paris.

Sourirajan, (1965), "Water Treatment Membrane Process", American Water Works Association Research Fondation, Lyonnaise des Eaux, Water Research Commision of South Africa

Wenten, I.G., (2002), "Perkembangan Terkini di Bidang Teknologi Membran dan Potensinya untuk Pengelolaan Sumber Daya Alam", Prosiding Seminar Nasional Rekayasa dan Proses, Jurusan Teknik Kimia UNDIP Semarang.

Widjaja A., (2000), http://www.kompas.com/kompascetak/0209/19/daerah/buay25.htm, di akses pada tanggal 21 November 2002

Zeman, L.J. and A.L. Zydney, (1996), "Ultrafiltration and Microfiltration Principles and Application", New York, John Wiley \& Sons. 